\title{
Alcohol labelling rules in free trade agreements: advancing the industry's interests at the expense of the public's health
}

Deborah Gleeson ${ }^{1}$, Paula O’Brien

${ }^{1}$ School of Psychology and Public Health, La Trobe University, Melbourne, Australia

${ }^{2}$ Melbourne Law School, The University of Melbourne, Melbourne, Australia

Deborah Gleeson PhD, Senior Lecturer, Paula O’Brien PhD, Senior Lecturer.

Correspondence to: Dr Deborah Gleeson, School of Psychology and Public Health, La Trobe University, Vic. 3086, Australia. Tel: +61 39479 3262; Email:

d.gleeson@latrobe.edu.au

Running head: Alcohol labelling rules in free trade agreements

This is the author manuscript accepted for publication and has undergone full peer review but has not been through the copyediting, typesetting, pagination and proofreading process, which may lead to differences between this version and the Version of Record. Please cite this article as doi: 10.1111/dar.13054

This article is protected by copyright. All rights reserved. 


\begin{abstract}
Introduction and aims: The Trans-Pacific Partnership Agreement (TPP) included novel rules for wine and spirits requiring parties to allow wine and spirits importers to display information required by the importing country on a supplementary label rather than on the standard label. Since the TPP negotiations concluded, alcohol-specific supplementary labelling rules have begun to appear in other trade agreements. The aim of this paper was to map the new instruments containing these rules and examine developments in the rules with implications for health information on alcohol containers.

Design and methods: Trade agreements signed after the TPP negotiations concluded were retrieved and searched for alcohol-specific labelling provisions. A comparative legal analysis of these provisions and related exceptions was undertaken.

Results: Supplementary labelling rules similar or identical to those in the TPP have been included in five subsequent trade agreements. The United States-Mexico-Canada Agreement also includes several additional provisions about alcohol labelling. Exceptions in the agreements provide some space for governments to defend labelling measure that might otherwise breach the rules, in the event of a dispute.

Discussion and conclusions: By securing these rules, the alcohol industry is better positioned to claim the space on the standard label as industry 'real estate' and to oppose mandatory health information incorporated into the standard labelling. These risks can be mitigated by stemming the adoption of supplementary labelling rules in further trade agreements; clarifying the text of agreements and ensuring that regulators understand that the rules do not prevent the use of 'best-practice' warning labels.
\end{abstract}

Keywords: alcohol labelling, trade agreements, supplementary labels, health information, health warning labels 


\section{Introduction}

Alcohol consumption can lead to acute and chronic health problems for the drinker and third parties, including injuries, communicable diseases, non-communicable diseases such as cancer and mental illness, and disabilities, such as foetal alcohol spectrum disorder [1]. At a population level, such harms far outweigh the supposed health benefits associated with imbibing [2, 3]. The World Health Organization (WHO) estimates that 5.3\% of all deaths, $7.2 \%$ of all premature mortality (69 years and under) and 5.1\% of diseases worldwide in 2016 were attributable to alcohol [4]. Alcohol is ranked as the seventh leading risk factor for death and disability in the latest Global Burden of Disease study [5]. Despite these harms, total per capital alcohol consumption has increased since 2005. The number of current drinkers has decreased globally, yet average population per capita alcohol consumption now sits at 6.4 litres per year [4]. If abstainers are excluded, it is 15.1 litres per year for drinkers aged 15+ years [4]. A rise in the number of persons drinking in China and the persistence of heavy episodic drinking account for at least some of the increase [4].

There are many policy options open to governments wanting to reduce the incidence of alcoholrelated harm in their populations. One of these is the inclusion of health warnings on alcohol containers. Although not one of the World Health Organization's three 'best buys' for alcohol control (being taxation, limitations on availability and restrictions on marking), the provision of information on the alcohol container label was recommended by the WHO in its 2010 Global Strategy to Reduce the Harmful Use of Alcohol [6]. By September 2019, 47 countries had introduced such mandatory health warnings [7], with a number of other countries having voluntary warning schemes. Although the take-up of alcohol health warning labels is still relatively low, the past few years has seen an escalation in the rate at which alcohol labelling policies are being introduced. In 1999, only nine countries had mandatory alcohol warnings [8]. A further seven countries had added labels by 2006 [9]. Over the last 10 years, government interest this policy option has grown and there are examples of countries, such as Thailand and South Korea, exploring tobacco-style graphic health warnings for alcohol [10]. Alcohol, being historically seen as separate to other foods, is also increasingly being labelled with the kinds of information common to foodstuffs, such as nutrition information panels [10].

This uptick in government interest in alcohol labelling coincides with, and is supported by, developments in the evidence base for alcohol health warning labels. Although the evidence of effects of alcohol warnings on actual consumption has been weak, based as it has been on the United States alcohol warning labels [11], recent studies of sample labels have started to show effects of labels on intermediary variables, such as intentions to reduce consumption [12, 13]. Furthermore, a recent experimental study from the Yukon Territories in Canada (which briefly introduced warnings about the increased risk of cancer from alcohol consumption) found that 
that the warnings were associated with a significant increase in awareness of alcohol's cancer risk and intentions to reduce consumption, and a decline in alcohol sales [14, 15]. However, the rationales for introducing alcohol health warnings may extend beyond immediate behaviour change. Arguably, the provision of label warnings fulfils a consumer's right to know the risks associated with products they are ingesting, a right which exists regardless of the use that the consumer makes of the information. Labels may also serve a normative or 'symbolic' purpose [16], marking alcohol out as a 'special or hazardous' commodity [16] and potentially contributing to a change in what Edwards called the 'social climate' around alcohol [17, p. 178]. Although difficult to study, one measure of the effect of alcohol warning labels on society's conceptualisation of the product may be its receptiveness to alcohol control measures. The recent Yukon study showed cancer warning labels were associated with greater support for pricing policies to reduce harm [14]. The potential for alcohol warning labels to have these multiple effects is a grave threat to the industry and underpins its opposition to the labels.

The alcohol industry has used various means to attempt to stymie effective alcohol labelling policy. These include threatening litigation against governments that introduce labelling policies that clash with the industry's interests. For example, the alcohol industry alleged that the Yukon Government's warning labels about alcohol and cancer constituted defamation [18]. This article is concerned with another strategy used by the industry to undercut public health labelling of alcoholic beverages and to preserve the label space for industry messaging: the creation of new rules to govern the supplementary labelling of alcohol beverages under preferential trade agreements. The agreements negotiated under the auspices of the World Trade Organization (WTO), such as the Agreement on Technical Barriers to Trade ('TBT Agreement'), do not include specific rules for alcohol labelling. The general disciplines in the TBT Agreement do apply to alcohol and have arguably been used to apply pressure to some governments not to introduce good labelling policies [19, 20]. But it seems that the alcohol industry is not satisfied with the trade protections offered by the WTO, and has sought additional rules in preferential trade agreements to help further protect the space on the label as industry 'real estate' [21]. Rules specifically applying to supplementary labelling of alcoholic beverages (wine and spirits) began to appear in trade agreements with the negotiation of the Trans-Pacific Partnership Agreement (TPP), a large regional trade agreement signed by 12 parties in October 2015, which ultimately collapsed following the withdrawal of the United States. The supplementary labelling rules were then salvaged and incorporated into the Comprehensive and Progressive Agreement for Trans-Pacific Partnership (CPTPP) agreed between the 11 remaining parties, and have since been included in several other trade agreements negotiated by states that were involved in negotiating the TPP.

The proliferation of these alcohol-specific supplementary labelling rules in new preferential trade agreements potentially poses a problem for public health. It is possible that the alcohol 
industry and governments with strong alcohol export interests may use these rules to argue against progressive alcohol labelling policies. It is therefore important to understand the prevalence and content of these rules, and to assess their threat to public health labelling. The aims of this paper are therefore to:

- Map the agreements in which alcohol-specific supplementary labelling rules are appearing and the geographic spread of the rules through trade agreements;

- Describe the types of alcohol-specific supplementary labelling rules appearing in free trade agreements; and

- Examine developments in the rules (their location in the agreement texts, significant changes to the provisions, and the use of exceptions).

\section{Methods}

We searched for preferential trade agreements (bilateral and regional), signed after the date negotiations for the TPP concluded (5 October 2015), including agreements in force and agreements signed but not yet in force. Our rationale for limiting the search to trade agreements signed following the conclusion of the final TPP text was that we assumed that the alcoholspecific supplementary labelling provisions that appeared in the TPP were first developed during the negotiations of that agreement, and their adoption in other trade agreements would therefore be likely to post-date the conclusion of the TPP.

Document retrieval involved two steps. First, we searched the WTO's Regional Trade Agreements (RTA) database (http://rtais.wto.org/UI/PublicMaintainRTAHome.aspx) for agreements signed since 5 October 2015 that were notified to the WTO and included in the database. WTO members are required to notify the WTO when they conclude negotiations for an RTA, accede to (join) an existing agreement, or change an existing agreement [22]. Notification is meant to occur promptly, however the timing of notifications can vary [22], meaning that the database may not include all concluded agreements, particularly if they have not yet been implemented. Next, we searched the websites of trade negotiating authorities in each of the TPP Parties for agreements concluded since 5 October 2015 that may not have been notified to the WTO yet. The searches were conducted in August 2019.

Twenty-three trade agreements signed after 5 October 2015 were retrieved, including 17 identified from the WTO RTA database and 6 additional agreements identified from searches of government websites. Trade agreements where the text of the agreement was not available in English were excluded ( $n=4)$.

For each of the trade agreements included at this stage $(n=19)$, we searched the text for the terms 'wine', spirit*', 'beer', 'alcohol', 'supplementary' and 'label*' to identify agreements 
that potentially contained provisions relating to alcohol labelling for further review. Trade agreements were excluded at this stage if they did not contain any of the search terms or if the terms were not used in the context of alcohol labelling $(n=14)$, leaving 5 agreements containing alcohol-specific supplementary labelling provisions in our final dataset. The search strategy is shown in Figure 1 and the trade agreements retrieved are shown in Table 1, with the final agreements included in the data set shown using grey shading.

We then extracted text relevant to alcohol labelling from the included agreements (noting its location in the text), tabulated the data for comparison and undertook a legal analysis of the provisions relating to supplementary labelling provisions and any exceptions that apply to them. This involved the legal interpretation of the texts and their comparison. As the TPP was the first appearance of alcohol-specific labelling rules, this agreement was taken as the baseline for comparison.

\section{INSERT FIGURE 1 HERE}

\section{INSERT TABLE 1 HERE}

\section{Results}

The search found that, subsequent to the signing of the TPP, the following five agreements (listed in chronological order) have included supplementary labelling provisions specific to alcohol: Comprehensive and Progressive Agreement for Trans-Pacific Partnership, Agreement to Amend the Singapore-Australia Free Trade Agreement (SAFTA Amendment), PeruAustralia Free Trade Agreement (PAFTA), United States-Mexico-Canada Agreement (USMCA) and the Australia-Hong Kong Free Trade Agreement (A-HKFTA). In this section, first the alcohol labelling provisions of the TPP and CPTPP are examined together as the CPTPP is almost entirely constituted by the text of the TPP. Second, the SAFTA, PAFTA and A-HKFTA are discussed together as they all have Australia as a party. Third, the USMCA is considered separately.

\section{TPP/CPTPP}

The TPP was concluded in October 2015 and signed on 4 February 2016 by 12 parties: Australia, Brunei Darussalam, Canada, Chile, Japan, Malaysia, Mexico, Peru, New Zealand, Singapore, United States and Vietnam. At the time of signing, the 12 parties represented over $37 \%$ of global GDP and almost 26\% of global trade [23]. However, the agreement did not enter into force because President Donald Trump withdrew the US from the TPP on the second day of his term in office [24]. Most of the provisions of the TPP were salvaged by the remaining 
signatories and incorporated, by reference, into a new agreement, the CPTPP. The CPTPP was signed on 8 March 2018 and entered into force from 30 December 2018 for several of the parties, including Australia (with some others still to complete their domestic ratification processes). At signing, the 11 remaining parties represented $13.3 \%$ of global GDP and $14.45 \%$ of global trade, and the total population of the СРТРP countries was estimated at 499 million [25].

The TPP included rules on the labelling of wine and spirits that had not been seen in any previous preferential trade agreement. The TPP rules have been incorporated in their entirety, by reference, into the CРТPP. These rules require parties to allow wine and spirits importers to place country-specific labelling information on a 'supplementary label', rather than having to incorporate it into the existing labels ('TPP supplementary label rules') [26]. The TPP supplementary label rules in relation to distilled spirits state:

If a Party requires a supplier to indicate information on a distilled spirits label, the party shall permit the supplier to indicate that information on a supplementary label that is affixed to the distilled spirits container. (para 5)

Similar provision is made for supplementary labelling of wine, except for the following labelling information: the product name, country of origin, net contents, and alcohol content, which must be presented in a single field of vision or, if not, in accordance with each party's laws.

What is a 'supplementary label'? The term is not explicitly defined in the TPP text. A sound reading of the TPP would suggest that it is 'a label that is affixed to the product, ... additional to the standard or principal product labels, and ...generally used as an alternative to removing the standard or principal labels and relabelling the container with the conforming label.' [27, p. 380]. The TPP also seems to require that a supplementary label has some permanence and that it cannot just be a tag slung around the neck of a bottle. For example, a supplementary label could be a new sticker label placed over the original back label of a wine bottle to include country-specific information, such as a health warning required in the importing country but not in the producer's home country. The TPP also provides that, 'if there is more than one label on a container of wine or distilled spirits, a Party may require that each label be visible and not obscure mandatory information on another label.' [27, p. 380].

However, we are concerned that the industry and exporting countries may attempt to argue that the term 'supplementary label' means 'an additional label that can fit into some unused space on the container and that does not interfere with the standard labels' [27, p. 381]. Such an argument would be aimed, at a minimum, at preventing governments from prescribing labelling 
features, such as size, position and design, but the ultimate aim is likely to convince government not to require health information on alcoholic beverage labels at all. Such an argument, if it were made, would be consistent with industry opposition to design and placement features of warning labels in other trade forums such as the WTO Committee on Technical Barriers to Trade [10]. We do not consider that this interpretation of the TPP supplementary labelling rules is correct as a matter of law. Furthermore, it is important to note that even if the pro-industry definition of supplementary labelling were correct, the TPP/CPTPP contains a public health exception that can be used to legitimise a government measure which was considered to be inconsistent with the industry's broad reading of the supplementary labelling rule. Article 29.1 of the TPP incorporates the public health exception from the WTO General Agreement on Tariffs and Trade 1994 [28], which provides as follows:

Subject to the requirement that such measures are not applied in a manner which would constitute a means of arbitrary or unjustifiable discrimination between countries where the same conditions prevail, or a disguised restriction on international trade, nothing in this Agreement shall be construed to prevent the adoption or enforcement by any contracting parties of measures: ... (b) necessary to protect human, animal or plant life or health ...

In order to come within the protection afforded by such a public health exception, government would need to demonstrate that insisting that health information about alcohol be presented on the front of the bottle and not on a supplementary label is necessary to protect human health or life [27], and that the 'chapeau' requirements (i.e. the requirements in the introductory part of the exception, which apply to the exception in its entirety) that the measure is not unlawfully discriminatory or a disguised restriction on trade are met. Focussing on the necessity test, this is likely to be understood, in light of WTO jurisprudence, as meaning there are no less traderestrictive measures reasonably available that could make a contribution to the member's health objective equal to that of the contested measure [27]. In this instance, this requires proof that a warning on a supplementary label would not be as effective in communicating its message to the public as one which meets the government's preferred size, positioning, and design.

Although the public health exception likely offers a reasonable measure of protection to alcohol labelling measures should a matter ever be formally litigated, the existence of the obligation to allow for supplementary labelling of wine and spirits opens up a new avenue for the alcohol industry's arguments against alcohol labelling. Government regulators, without a deep knowledge of trade law, may be swayed by the industry's arguments and regard it as unlawful to prescribe labelling requirements which would run counter to the laissez-faire approach which supplementary labelling reflects. This may lead to government giving up on alcohol labelling or implementing policies which do not reflect the evidence base about what makes labels effective. 
Our review of trade agreements signed since suggest 5 October suggests that the TPP supplementary labelling rules have been exported to three other preferential trade agreements (or amendments thereto) negotiated by Australia since the signing of the TPP. The TPP was always intended to provide a model for the next generation of free trade agreements [29] and it seems that the TPP supplementary label rules have become a standard feature in the negotiation of new trade agreements involving Australia. (It is notable, however, that they have not been ultimately adopted in all the agreements negotiated by Australia since the TPP. For example, they do not appear in the final text of the Indonesia-Australia Comprehensive Economic Partnership Agreement.)

On 13 October 2016, Australia and Singapore signed the SAFTA Amendment. It came into effect on 1 December 2017. The TPP supplementary label rules have been copied verbatim into the SAFTA Amendment in Sectoral Annex 5C on Wine and Distilled Spirits, paras 5 and 10 [30]. Singapore is a party to the CPTPP, so the inclusion of the TPP supplementary label rules in SAFTA Amendment repeats the commitments already made by Australia and Singapore in relation to supplementary labelling of wine and spirits.

On 12 February 2018 [31], Peru and Australia signed the PAFTA, which also includes the TPP supplementary label rules for wine and distilled spirits in an Annex on Wine and Distilled Spirits [32]. PAFTA is not yet in force. Peru is also one the parties to the CPTPP.

On 26 March 2019 [33], Australia and Hong Kong signed A-HKFTA [34]. Like the SAFTA Amendment and PAFTA, it also includes the TPP supplementary labelling rules in Annex 5-A but only in relation to wine [34]. A-HKFTA is also not yet in force. Hong Kong is not a member of the CPTPP.

These three agreements also include the same general public health exception as discussed above in relation to the TPP/CPTPP. The public health exception applies to the entirety of each agreement and is not specific to supplementary labelling of alcohol. However, a distinguishing feature of the A-HKFTA, compared to the TPP/CPTPP, SAFTA and PAFTA, is that it includes the following exclusion specifically for supplementary labelling of wine (A-HKFTA special exception):

'for greater certainty, notwithstanding [the supplementary label rules], a party may impose any labelling requirement to fulfil a legitimate objective, such as for the 
protection of human health and safety, in accordance with the [WTO] TBT Agreement.'(Annex 5-A para 10) [34].

This exception is placed in the same Annex as the supplementary labelling rules. Is this addition beneficial from a public health perspective? The provision does not clarify the meaning of supplementary labelling so as to refute the interpretation of a supplementary label as one that fits into an unused space on a container. Rather, the provision is in the form of exception to the TPP supplementary labelling rule. On its face, it seems more generous than the general public health exception because it does not use the necessity test or impose the chapeau requirements found in the TPP/CPTPP, the SAFTA Amendment and the PAFTA. However, the A-HKFTA special exception requires that, in order to 'save' a government's labelling measure which otherwise breaches the TPP supplementary labelling rules, the labelling measure must be consistent with the WTO TBT Agreement. This link to the TBT Agreement, effectively, reintroduces the necessity requirement. The TBT Agreement article 2.2 demands that 'technical regulations', such as labelling rules, not be more trade-restrictive than is necessary to achieve a WTO member government's legitimate health objectives [35, Article 2.2]. The test for this art 2.2 rule against unnecessary trade-restrictiveness is very similar to the test used to determine the necessity of a measure under the public health exception [27]. The result is that the AHKFTA special exception may not offer much more protection to government labelling measures than the public health exception.

\section{United States-Mexico-Canada Agreement}

We have also found that the TPP supplementary label rules have made their way into the United States-Mexico-Canada Agreement (USMCA) [36], which was signed on 30 November 2018 but is not yet in force. It is the renegotiated form of the North American Free Trade Agreement that had been in effect since 1 January 1994. USMCA includes the TPP supplementary label rules in relation to wine and spirits (Annex 3-C, art 3.C.3, paras 5 and 12) [36]. The supplementary label rules do not appear as an annex to the chapter on Technical Barriers to Trade (as is the case with the TPP and other agreements), but in an annex to the Agriculture chapter. The rule is subject to the same general public health exception found in the TPP/СРTPP (art 32.1(1)). The text of the specific labelling exception found in the A-HKFTA is not included here.

There are two points of further interest in the USMCA. Firstly, it includes some restriction on how supplementary labelling can be applied, compared to the TPP/CPTPP. It states that a party may require that there not be conflict between information on an existing label and a supplementary label (Annex 3-C, art 3.C.3, para 6) [36]. This seems like a positive 
development from a public health perspective as it serves to avoid mixed messages being sent by information on different labels on the product. For example, it prevents existing label information pertinent to the producer's home market (e.g. 'drinking is not permitted by those under 18 years') undermining the information required in the importing market and appearing on a supplementary label (e.g. 'drinking is not permitted by those under 21 years'). Secondly, and contrary to public health concerns about the label space being used as a marketing vehicle, is a provision requiring each party to allow wine and spirits containers to bear statements of quality, drawings, figures, and illustrations. This obligation is made subject to a party's ability to enforce its laws and regulations relating to health and safety (USMCA Annex 3-C, art 3.C.3, paras 26 and 27) [36]. This provision reinforces the industry’s primary control over the label.

\section{Discussion}

The spread of the TPP supplementary labelling rules into further preferential trade agreements and the emergence of additional alcohol-specific labelling rules in the USMCA runs counter to the public health objective of reducing alcohol consumption and harm. The best legal interpretation of the TPP supplementary labelling rules indicates that they do not impede the right of governments to mandate warnings and other health information on alcoholic beverages, including the content of the messages, the inclusion of graphics, their colours and font, and their size and position on the container. The general public health exception and the A-HKFTA specific alcohol exception provide further legal support for governments wishing to mandate labelling requirements which might prevent or limit industry control over label content and placement.

However, it should be recognised that the text of the TPP supplementary labelling rules opens a space for an argument against this interpretation and insistence that conformity with the rule requires that no design or placement limitations apply to label warnings or health information, lest the producer's right to use supplementary labels is thwarted. The lack of design and placement specifications for alcohol warning labels would undermine the effects of such labels, making government labelling policies less impactful than they otherwise could be. The evidence from alcohol labelling schemes without strong design and placement requirements shows that these labels have little effect on consumption behaviour [11]. The new research evidence confirms that well-designed labels can impact consumption [14, 15]. It is vital that regulatory space is left wide open for governments to implement forms of alcohol health information labelling which will benefit the public's health.

The inclusion of the TPP supplementary labelling rules in the A-HKFTA signals that Australia is seeking the wider adoption of the rules beyond the CPTPP parties. This is the first time the rules have been included in a preferential trade agreement with a non-signatory to the 
TPP/CPTPP. Bringing Hong Kong into the fold expands the geographic coverage of the rules to a further 7.5 million people [33]. The inclusion of supplementary labelling rules in the USMCA further expands the geographical and population coverage of the rules, by applying them to the US. The rules may also re-appear in future agreements negotiated by the US.

Negotiations for the Regional Comprehensive Economic Partnership (RCEP), another large preferential agreement, have recently concluded with signing of the agreement expected to take place in 2020. RCEP was originally negotiated by 16 nations: the 10 Association of Southeast Asian Nations and the six countries with which the Association has existing trade agreements (Australia, China, India, Japan, Republic of Korea and New Zealand) [37]. India withdrew from negotiations in 2019, but may return before signing. Seven of the countries involved in the negotiations, including Australia, are parties to the CTPPP. RCEP countries, together, have a population of 3,552 million and account for US\$25.4 trillion in GDP [37]. Adoption of the supplementary labelling rules in RCEP would expand the population affected by these rules by many millions of people. The text of the RCEP has not yet been released, and there have been no leaks of relevant parts of the agreement to date to determine whether the supplementary labelling rule was included.

Recently, the EU released a textual proposal for trade in wine, aromatised wine products and spirit drinks for the EU-New Zealand Free Trade Agreement, which also contains provisions for supplementary labels (Article X.10 [NZ X.7]) [38]. Although it is only a proposal at this stage, this development suggests that the concept of supplementary labels has gained acceptance among countries, including those in the EU, which did not participate in the negotiation of the original TPP supplementary labelling rules. Interestingly, EU textual proposals for the Technical Barriers to Trade Chapters of the EU-Australia and EU-New Zealand agreements propose to require that parties accept a supplementary label for any product, not confined to wine and spirits, and that parties 'endeavour to accept non-permanent or detachable labels, or marking or labelling in the accompanying documentation rather than physically attached to the product'. This type of provision could further undermine the effectiveness of warning schemes by allowing the use of labels that are able to be easily removed or lost (such as a tag on a string around the next of a bottle) or the use of QR codes which need to be scanned to obtain the relevant information. The problems with the latter are obvious, and research commissioned by the Brewers of Europe found that the majority consumers do not use online applications (which would include QR codes) to access information on nutritional values and ingredients about alcoholic beverages. Furthermore, 36\% were not at all interested and 28\% were undecided [39] about the use of online application to access alcohol nutrition information 
Given the possibility that the supplementary labelling rules may be used to argue against effective public health labelling policies, it would optimal if the rules were not included in any new preferential trade agreements, and we recommend that public health stakeholders raise awareness of the potential implications of these rules and advocate against their inclusion. However, if such provisions do continue in use, it is important for there to be clarification in the text of these agreement about how the provision is intended to operate. One option would be that existing or future agreements include text which confirms that health information is excluded from the operation of the TPP supplementary labelling rules. Use of the general term 'health information' rather than 'health warning' would ensure that other types of health information (such as nutrition information) are also excluded. An alternative, option would be for there to be a more far-reaching exception than in the A-HKFTA which makes the supplementary labelling rules subject to a party's right to impose any labelling requirements but without the additional hurdle that the labelling requirements be consistent with the TBT Agreement.

The above solutions apply to the negotiation of future agreements. What can be done to ensure that the TPP supplementary labelling rules do not stymie efforts to introduce sound labelling policies?

Firstly, it is essential that regulators develop an understanding of the proper meaning of the TPP supplementary label rules so as to combat 'regulatory chill' - the fear of regulating lest one's actions are subject to legal challenge - which such provisions can produce. In producing new labelling laws, regulators need to have confidence about the meaning of the applicable trade rules in order to resist arguments from the industry and other governments that seek to dampen down new labelling laws with claims of inconsistency with preferential trade agreements. It is therefore important that public health academics and advocates, with the assistance of legal experts, bring this issue to the attention of the relevant regulators, as well as responsible Ministers and interested members of parliament, through a variety of avenues such as informal briefings, formal consultation and submission processes, inquiry hearings and academic papers.

Secondly, where a regulator proceeds to set design and placement requirements for alcohol warning labels, the regulator and its government must be ready to defend the labelling measure against a formal challenge under the dispute settlement processes in the preferential trade agreement. Success in such circumstances will, in part, depend on technical legal arguments about the meaning of terms in the agreements, including 'supplementary label', but it will also depend to a significant extent on the state of the science about alcohol labelling. The evidence about the effects of alcohol labelling on consumers and the labelling conditions under which 
these effects are achieved will be crucial. It may also be possible to test the argument about alcohol labelling having a normative or symbolic purpose. A renewed global governance instrument for alcohol, developed on the basis of excellent science, might also serve to affirm the legitimacy of such labelling measures. The Framework Convention on Tobacco Control has played this exact role in establishing the legitimacy of tobacco plain packaging in the WTO [40].

Limitations of the study are largely related to the search strategy and data sources: we may not have been able to identify all trade agreements in which supplementary labelling rules for alcohol containers have appeared. First, the WTO RTA database does not represent a complete set of concluded trade agreements; some may be added later and it is possible that some concluded RTAs may never be notified or included in the database.. Second, because the relevant government websites for Chile and Peru were in Spanish only, we were unable to search them to identify trade agreements. It is also possible, although unlikely, that alcohol labelling provisions like those in the TPP appeared in other trade agreements concluded prior to the conclusion of the TPP (given the length of these negotiations). Finally, we were unable to retrieve the text of agreements in other languages (e.g. Spanish). Due to these limitations, we may have underestimated the uptake of alcohol-specific supplementary label rules in trade agreements.

It is likely that supplementary labelling rules for alcohol containers are actively being considered in current trade negotiations in many forums. Due to the confidentiality of negotiations for free trade agreements, documentary evidence is generally not available until agreements are signed (and negotiating documents are not usually released even after signing), except in the case of text proposals released by the EU (as discussed above). However, future research could explore other avenues for obtaining evidence, as well as examining trade agreements in languages other than English.

\section{Conclusions}

Placing health warnings on alcohol containers is an important strategy, among others, for addressing the considerable burden of alcohol-related harm. There is increasing global alcohol consumption and growing evidence supporting the use of alcohol health warnings, and evidence-based warnings seem to be a strategy of interest to several governments. In this context, it is important that states wanting to introduce effective warning schemes do not face unnecessary barriers to doing so. Many states proposing to introduce health warnings on alcohol containers have faced a range of objections at the WTO; objections which have likely resulted in some cases in proposed policy measures being delayed, weakened or shelved. The incorporation of alcohol-specific 'supplementary labelling' rules, first in the TPP and then 
subsequently in a number of other bilateral and regional agreements, risks providing a further deterrent. Strategies to mitigate these risks include stemming the adoption of supplementary labelling rules in further trade agreements; clarifying the text of agreements with supplementary labelling provisions to ensure that they do not create obstacles to states mandating the appearance and placement of health warnings; and reducing the potential for regulatory chill by ensuring that regulators understand that the supplementary labelling rules do not prevent the use of 'best-practice' warning labels. Employing these strategies will require leadership by public health academics and advocates to raise awareness of the issues and press for action, along with technical support from legal experts, to generate workable solutions and provide support to regulators.

\section{Acknowledgments}

The authors wish to thank Ashley Schram, Mark Jennings and Robin Room for helpful comments on earlier drafts of this paper.

\section{Conflicts of interest}

None to declare 


\section{References}

1. Babor TF, Caetano R, Casswell S, Edwards G, Giesbrecht N, Grabman G, et al. Alcohol: No Ordinary Commodity: Research and Public Policy. 2nd ed. Oxford: Oxford University Press; 2010.

2. Stockwell T, Zhao J, Panwar S, Roemer A, Naimi T, Chikritzhs T. Do "Moderate" Drinkers Have Reduced Mortality Risk? A Systematic Review and Meta-Analysis of Alcohol Consumption and AllCause Mortality. J Stud Alcohol Drugs 2016;77:185-98.

3. Chikritzhs T, Stockwell T, Naimi T, Andreasson S, Dangardt F, Liang W. Has the leaning tower of presumed health benefits from 'moderate' alcohol use finally collapsed? Addiction 2015;110:7267.

4. World Health Organization. WHO Global Status Report on Alcohol and Health 2018. Geneva: WHO; 2018.

5. Stanaway JD, Afshin A, Gakidou E, Lim SS, Abate D, Abate KH, et al. Global, regional, and national comparative risk assessment of 84 behavioural, environmental and occupational, and metabolic risks or clusters of risks for 195 countries and territories, 1990-2017: a systematic analysis for the Global Burden of Disease Study 2017. Lancet 2018;392:1923-94.

6. World Health Organization. Global Alcohol Strategy to Reduce the Harmful Use of Alcohol. Geneva: WHO; 2010. Available from:

http://apps.who.int/iris/bitstream/10665/94384/1/9789241506236 eng.pdf?ua=1, archived at https://perma.cc/LR4HGMDR

7. WHO Global Information System on Alcohol and Health (GISAH) [Internet]. WHO. [cited 28 September 2019]. Available from: https://www.who.int/gho/alcohol/en/.

8. Wilkinson BW. General Agreement on Tariffs and Trade (GATT). Can Encycl. 2017.

9. Stockwell T. A Review of research Into the Impact of Warning Labels on Attitudes and Behaviour: Centre for Addictions Research of BC; 2006. Available from:

https://www.uvic.ca/research/centres/cisur/assets/docs/report-impacts-alcohol-warning-labels.pdf. 10. O'Brien P, Mitchell A. On the bottle: Health Information, alcohol labelling and the WTO technical barriers to trade agreement. QUT Law Review 2018;18:124-55.

11. Greenfield TK. Warning Labels: Evidence on Harm Reduction from Long-term American Surveys (Chapter 7). In: Plant M, Single E, Stockwell T, editors. Alcohol Minimising the Harm: What Works?: Free Association Books; 1997.

12. Vallance K, Romanovska I, Stockwell T, Hammond D, Rosella L, Hobin E. "We Have a Right to Know": Exploring Consumer Opinions on Content, Design and Acceptability of Enhanced Alcohol Labels. Alcohol Alcohol 2017;53:20-5.

13. Hobin E, Vallance K, Zuo F, Stockwell T, Rosella L, Simniceanu A, et al. Testing the Efficacy of Alcohol Labels with Standard Drink Information and National Drinking Guidelines on Consumers' Ability to Estimate Alcohol Consumption. Alcohol Alcohol 2017;53:3-11.

14. Hobin E, Schoueri-Mychasiw N, Stockwell T, Hammond D, Shokar S, Vallance K, et al. Testing alcohol labels as a tool to communicate cancer risk to drinkers: a real-world quasi-experimental study. J Stud Alcohol Drugs. In press.

15. Zhao J, Stockwell T, Vallance K, Hobin E. The effects of alcohol warning labels on population alcohol consumption: an interrupted time-series analysis of alcohol sales in Yukon, Canada. J Stud Alcohol Drugs. In press.

16. Wilkinson C, Room R. Warnings on alcohol containers and advertisements: International experience and evidence on effects. Drug Alcohol Rev 2009;28:426-35.

This article is protected by copyright. All rights reserved. 
17. Edwards G. Alcohol Policy and the Public Good. Oxford; New York: Oxford University Press; 1994.

18. Stockwell T, Solomon R, O'Brien P, Vallance K, Hobin E. Cancer warning labels on alcohol containers: A consumer's right to know, a government's responsibility to inform, and an industry's power to thwart. J Stud Alcohol Drugs. Under review.

19. O'Brien P. Australia's double standard on Thailand's alcohol warning labels. Drug Alcohol Rev 2013;32:5-10.

20. Barlow P, Labonte R, McKee M, Stuckler D. Trade challenges at the World Trade Organization to national noncommunicable disease prevention policies: a thematic document analysis of trade and health policy space. PLoS Med 2018;15:e1002590

21. O'Brien P, Gleeson D, Room R, Wilkinson C. Commentary on 'Communicating Messages About Drinking': Using the 'Big Legal Guns' to Block Alcohol Health Warning Labels. Alcohol Alcohol 2018;53:333-6.

22. World Trade Organization. Technical Cooperation Handbook on Notification Requirements: Legal Provisions Relating to Regional Trade Agreements. n.d. Available from:

https://www.wto.org/english/tratop e/region e/region e.htm

23. Australian Government Department of Foreign Affairs and Trade. Trans-Pacific Partnership Agreement [Available from: http://dfat.gov.au/trade/agreements/tpp/pages/trans-pacificpartnership-agreement-tpp.aspx, archived at https://perma.cc/HXQ9-HLF8.

24. Trump D. Presidential Memorandum regarding Withdrawal of the United States from the Trans-Pacific Partnership Negotiations and Agreement: Memorandum for the United States Trade Representative. 23 January 2017. Available from: www.whitehouse.gov/the-pressoffice/2017/01/23/presidential-memorandum-regarding-withdrawal-united-states-trans-pacific, archived at https://perma.cc/PET3-EU4C.

25. Australian Government Department of Foreign Affairs and Trade. Comprehensive and Progressive Agreement for Trans-Pacific Partnership: CPTPP Text and Associated Documents Canberra: DFAT. Available from: https://dfat.gov.au/trade/agreements/in-force/cptpp/officialdocuments/Pages/official-documents.aspx.

26. Trans Pacific Partnership. Chapter 8: Technical Barriers to Trade: Ministry of Foreign Affairs and Trade; 2016 [Available from: https://www.mfat.govt.nz/assets/Trans-PacificPartnership/Text/8.-Technical-Barriers-to-Trade-Chapter.pdf.

27. O'Brien P, Gleeson D, Room R, Wilkinson C. Marginalising health information: implications of the Trans Pacific Partnership for alcohol labelling. Melb Univy Law Rev 2017;41:341-91.

28. Organization WT. General Agreement on Tariffs and Trade 1994. 1994. Available from: https://www.wto.org/english/docs e/legal e/06-gatt e.htm.

29. Fergusson IF, McMinimy MA, Williams BR. The Trans-Pacific Partnership (TPP) Negotiations and Issues for Congress (Congressional Research Service No R42694). Washington D.C.:

Congressional Research Service; 20 March 2015.

30. Government of Australia and Government of the Republic of Singapore. Agreement to Amend the Singapore-Australia Free Trade Agreement; 28 September 2019. Available from: https://dfat.gov.au/trade/agreements/in-force/safta/Documents/agreement-to-amend-thesingapore-australia-free-trade-agreement.pdf.

31. Australian Government Department of Foreign Affairs and Trade. Peru-Australia Free Trade Agreement [Available from: https://dfat.gov.au/trade/agreements/not-yet-in-

force/pafta/Pages/peru-australia-fta.aspx.

This article is protected by copyright. All rights reserved. 
32. Australian Government Department of Foreign Affairs and Trade. Peru-Australia Free Trade Agreement: PAFTA Text and Associated Documents [Available from:

https://dfat.gov.au/trade/agreements/not-yet-in-force/pafta/full-text/Pages/fta-text-andassociated-documents.aspx.

33. Australian Government Department of Foreign Affairs and Trade. Australia-Hong Kong Free Trade Agreement [Available from: https://dfat.gov.au/trade/agreements/not-yet-in-force/ahkfta/Pages/default.aspx.

34. Australian Government Department of Foreign Affairs and Trade. Australia-Hong Kong Free Trade Agreement: A-HKFTA Text and Associated Documents [Available from:

https://dfat.gov.au/trade/agreements/not-yet-in-force/a-hkfta/a-hkfta-text/Pages/default.aspx.

35. World Trade Organization. Agreement on Technical Barriers to Trade 1995. Available from: https://www.wto.org/english/docs e/legal e/17-tbt e.htm.

36. Office of the United States Trade Representative. Agreement between the United States of America, the United Mexican States, and Canada Text. Available from: https://ustr.gov/trade-

agreements/free-trade-agreements/united-states-mexico-canada-agreement/agreement-between.

37. Australian Government Department of Foreign Affairs and Trade. Regional Comprehensive Economic Partnership [Available from:

https://dfat.gov.au/trade/agreements/negotiations/rcep/Pages/regional-comprehensive-economicpartnership.aspx.

38. European Commission. Trade in Wine, Aromatised Wine Products and Spirit Drinks [EU proposal for the EU-New Zealand FTA]. May 6 2019. Available from:

https://trade.ec.europa.eu/doclib/docs/2019/june/tradoc 157926.pdf.

39. GfK Belgium. Consumer Insights: Knowledge of Ingredient and Nutrition Information of Alcoholic Beverages: Off-label Information and Its Use. September 2014.

40. World Trade Organization. Panel Report, Australia - Certain Measures Concerning Trademarks, Geographical Indications and Other Plain Packaging Requirements Applicable to Tobacco Products and Packaging, WTO Docs WT/DS435/R, WT/DS441/R, WT/DS458/R, WT/DS467/R (28 June 2018). Geneva: WTO; 2018, June 28.

This article is protected by copyright. All rights reserved. 


\section{Figure 1: Search strategy}

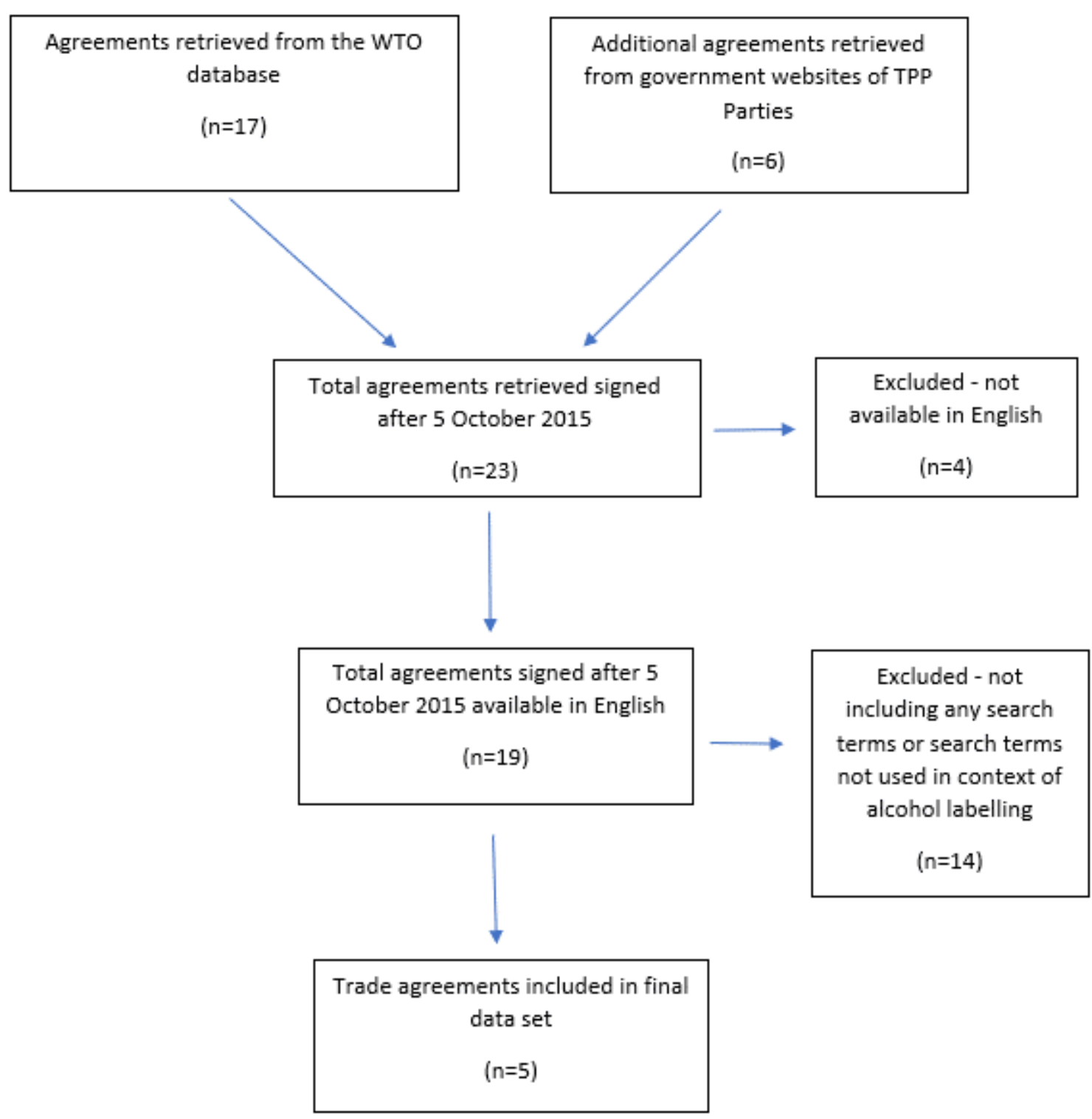

Note: The trade negotiating authorities for each of the TPP parties are: Australia - Department of Foreign Affairs and Trade; Brunei - Ministry of Foreign Affairs; Canada - Government of Canada; Japan - Ministry of Economy, Trade and Industry; Malaysia - The Official Portal Of Malaysia External Trade Development Corporation, The National Trade Promotion Agency of Malaysia; Mexico - Secretaría de Economía; New Zealand - Ministry of Foreign Affairs and Trade; Singapore Ministry of Trade and Industry, Enterprise Singapore; United States - Office of the United States Trade Representative; Vietnam - Trade Information Portal. Relevant government websites for Chile 
and Peru were unable to be located and reviewed in English. TPP, Trans-Pacific Partnership Agreement; World Trade Organization.

This article is protected by copyright. All rights reserved. 
Table 1: Trade agreements signed after the conclusion of the TPP negotiations

\begin{tabular}{|c|c|c|c|c|}
\hline $\begin{array}{l}\text { Date of } \\
\text { signature } \\
\text { (month, year) }\end{array}$ & Agreement & $\begin{array}{l}\text { Date of } \\
\text { entry into } \\
\text { force, if } \\
\text { applicable } \\
\text { (month, } \\
\text { year) }\end{array}$ & $\begin{array}{l}\text { Available } \\
\text { in } \\
\text { English }\end{array}$ & $\begin{array}{l}\text { Search terms } \\
\text { used in context } \\
\text { of alcohol } \\
\text { labelling }\end{array}$ \\
\hline April 2016 & $\begin{array}{l}\text { European Free Trade } \text { Association }^{\mathrm{a}}- \\
\text { Philippines }\end{array}$ & June 2018 & Yes & No \\
\hline June 2016 & Argentina - Brazil & July 2016 & No & N/A \\
\hline June 2016 & $\begin{array}{l}\text { European Union - Southern African } \\
\text { Development Community }^{\mathrm{d}}\end{array}$ & October 2016 & Yes & No \\
\hline July 2016 & Canada - Ukraine & August 2017 & Yes & No \\
\hline July 2016 & $\begin{array}{llll}\text { European } & \text { Free } & \text { Trade } & \text { Association }^{\mathrm{a}} \\
\text { Georgia } & & & \\
\end{array}$ & $\begin{array}{l}\text { September } \\
2017\end{array}$ & Yes & No \\
\hline July 2016 & Southern Common Market ${ }^{\mathrm{C}}$ - Mexico & $\begin{array}{l}\text { December } \\
2016\end{array}$ & No & N/A \\
\hline July 2016 & European Union - Ghana & $\begin{array}{l}\text { December } \\
2016\end{array}$ & Yes & No \\
\hline October 2016 & European Union - Canada & $\begin{array}{l}\text { September } \\
2017\end{array}$ & Yes & No \\
\hline November 2016 & Turkey - Singapore & October 2017 & Yes & No \\
\hline November 2016 & Southern Common Market ${ }^{\mathrm{C}}$ - Chile & March 2017 & No & N/A \\
\hline February 2017 & El Salvador - Ecuador & $\begin{array}{l}\text { November } \\
2017\end{array}$ & No & N/A \\
\hline May 2017 & China - Georgia & January 2018 & Yes & No \\
\hline October 2017 & Hong Kong, China - Macao, China & October 2017 & Yes & No \\
\hline March 2018 & $\begin{array}{l}\text { Comprehensive } \quad \text { and } \quad \text { Progressive } \\
\text { Agreement for Trans-Pacific Partnership }\end{array}$ & $\begin{array}{l}\text { December } \\
2018\end{array}$ & Yes & Yes \\
\hline June 2018 & Hong Kong, China - Georgia & $\begin{array}{l}\text { February } \\
2019 \\
\end{array}$ & Yes & No \\
\hline June 2018 & $\begin{array}{llll}\text { European } & \text { Free } & \text { Trade } & \text { Association }^{\mathrm{a}} \\
\text { Ecuador } & & & \end{array}$ & $\begin{array}{l}\text { Not yet in } \\
\text { force }\end{array}$ & Yes & No \\
\hline \multirow[t]{2}{*}{ December 2018} & $\begin{array}{llll}\text { European } & \text { Free } & \text { Trade } & \text { Association }{ }^{\mathrm{a}} \\
\text { Indonesia } & & & \end{array}$ & $\begin{array}{l}\text { Not yet in } \\
\text { force }\end{array}$ & Yes & No \\
\hline & \multicolumn{4}{|c|}{ Agreements retrieved from government websites of TPP parties } \\
\hline October 2016 & $\begin{array}{l}\text { Agreement to Amend the Singapore- } \\
\text { Australia Free Trade Agreement }\end{array}$ & $\begin{array}{l}\text { December } \\
2017\end{array}$ & Yes & Yes \\
\hline June 2017 & $\begin{array}{l}\text { Pacific Agreement on Closer Economic } \\
\text { Relations Plus }^{\mathrm{e}}\end{array}$ & $\begin{array}{l}\text { Not yet in } \\
\text { force }\end{array}$ & Yes & No \\
\hline
\end{tabular}




\begin{tabular}{|l|l|l|l|l|}
\hline February 2018 & Peru-Australia Free Trade Agreement & $\begin{array}{l}\text { February } \\
2020\end{array}$ & Yes & Yes \\
\hline November 2018 & United States-Mexico-Canada Agreement & $\begin{array}{l}\text { Not yet in } \\
\text { force }\end{array}$ & Yes & Yes \\
\hline March 2019 & $\begin{array}{l}\text { Australia-Indonesia Comprehensive } \\
\text { Economic Partnership Agreement }\end{array}$ & $\begin{array}{l}\text { Not yet in } \\
\text { force }\end{array}$ & Yes & No \\
\hline March 2019 & $\begin{array}{l}\text { Hong-Kong Australia Free Trade } \\
\text { Agreement }\end{array}$ & January 2020 & Yes & Yes \\
\hline
\end{tabular}

a Georgia; Iceland; Liechtenstein; Norway; Switzerland. b Australia; Brunei Darussalam; Canada; Chile; Japan; Malaysia; Mexico; New Zealand; Peru; Singapore; Vietnam. c Argentina; Brazil; Paraguay; Uruguay. d Botswana; Eswatini; Lesotho; Mozambique; Namibia; South Africa. e Australia; New Zealand; Cook Islands; Kiribati; Nauru; Niue; Samoa; Solomon Islands; Tonga; Tuvalu and Vanuatu. TPP, Trans-Pacific Partnership Agreement 


\section{University Library}

\section{- M M N E R VA A gateway to Melbourne's research publications}

Minerva Access is the Institutional Repository of The University of Melbourne

Author/s:

Gleeson, D;O'Brien, P

Title:

Alcohol Labelling Rules in Free Trade Agreements: Advancing the Industry's Interests at the Expense of the Public's Health

Date:

2021

Citation:

Gleeson, D. \& O'Brien, P. (2021). Alcohol Labelling Rules in Free Trade Agreements:

Advancing the Industry's Interests at the Expense of the Public's Health. Drug and Alcohol Review, 40 (1), pp.31-40. https://doi.org/10.1111/dar.13054.

Persistent Link:

http://hdl.handle.net/11343/275598 